\title{
薬物治療における医薬品安全性の推進に向けて薬学が果たす役割
}

佐 藤 光利

\section{Role of Pharmacy in the Promotion of Drug Safety in Pharmacotherapy}

\author{
Mitsutoshi Satoh
}

Faculty of Pharmaceutical Sciences, Meiji Pharmaceutical University; 2-522-1 Noshio, Kiyose, Tokyo 204-8588, Japan.

われわれの健康維持や疾病の治療において, 薬物 治療は中心的な役割を果たしている. 特にがんや免 疫疾患などの難治性疾患に対しては高度な治療が行 われ，多くの高活性の医薬品が使用される。このよ うな中で, 有効で安全性が高い薬物療法を提供する には，医療現場で薬を使用する医師や薬剤師，薬に ついて創薬・研究する製薬企業や研究所, 薬に関す る研究・教育を行う大学の研究者が重要な役割を果 たすのは言うまでもない。特に，小児や高齢者では 合併症による複雑な多剂併用による治療により，薬 剂による副作用の症状と原疾患の症状とが区別し難 いものもあり，それらの鑑別も重要である. 副作用 が発生した際，複数の薬剤を服用しているときに は，どの薬剂が原因であるかを特定する検査法の開 発が必要になる。また，がん化学療法においては嘔 気・嘔吐の消化器症状や骨髄抑制などの血液毒性に 対しては予防・治療する薬剤が開発されている一方 で，いまだに対応できない副作用もある．近年，抗 体医薬品に代表されるように高い治療効果を有する 医薬品が使用されるようになり，重大な副作用に至 る場合もあることからも副作用の情報収集も重要に なる.

日本薬学会第 137 年会（平成 29 年 3 月，仙台） にて企画したシンポジウムS07「薬物治療における 医薬品安全性の推進に向けて薬学が果たす役割」で は薬物治療で用いられる医薬品の安全性にフォーカ スをあて, 薬学が果たす役割について今後の方向性 を考えるうえで臨床現場での経験を持つ研究者, 製 薬企業で医薬品の安全性に関与している医薬品開発

明治薬科大学薬学部 (T204-8588 東京都清瀬市野塩 2522-1)

e-mail: satoh@my-pharm.ac.jp

日本薬学会第 137 年会シンポジウム S07 序文
者, 並びに大学における研究教育者にご講演頂いた.

はじめに千葉科学大学/共栄堂 宇野勝次博士より 「薬剤アレルギーの発症機構とその診断検査への取 り組み」というタイトルで, 薬剂アレルギーのメカ ニズムについて, 薬物の抗原形成後, 抗原提示細胞 の主要組織適合遺伝子複合体（major histocompatibility complex; MHC) class II 結合した薬物 抗原の提示によって薬物感作へルパー $\mathrm{T}$ 細胞 (Th) は Th1，Th2 あるいは Th17へ分化し，これによつ て発生する Th1 及びTh2によるアレルギー誘発に ついて解説された。 そして, 薬剤性アレルギーの診 断には患者のリスクや負担が少ない in vitro 試験の 細胞性試験が血清学的試験よりも有効であり，ケモ タキシス・チャンバー法による白血球遊走試験 (leukocyte migration test; LMT) が現在最も感度が 高く約 8 割の起因薬を検出することができることを 示し, 臨床での実際について紹介された.

東京理科大学 花輪剛久博士より「がん化学療法 における副作用に対する『患者に優しい製剤』の開 発」というタイトルで，がん治療の化学療法・放射 線療法により口腔粘膜炎は発生し, 激しい痛み・出 血を伴い, 咀嚼・嚥下障害, 睡眠障害などを引き起 こし，さらに，会話・薬剂の経口投与等が困難とな り, 治療意欲の低下や Quality of Life 低下の原因と なることが示され，がん化学療法・放射線療法によ り生じる口腔粘膜炎治療をターゲットに新しく開発 している製剤に関する知見が紹介された。水に難溶 解性のイルソグラジンマレイン酸を主薬とした薬剤 の溶解性を向上させることで有効性を向上させ, さ らに主薬の口腔内滞留性を上昇させることで，利便 性と使用感に優れた「患者に優しい製剂」の開発を 試みていることが示された。

中外製薬株式会社 大箸義章博士より「最近の新 
規医薬品に関する安全使用に係わる現状と課題」と いうタイトルで，世界をターゲットにしたバイオ医 薬品や分子標的治療薬など，革新的な作用機序を持 つ医薬品のそれぞれ特徵的な有害事象は，グローバ ルに医薬品の適正使用を推進することが重要であ り，医療現場で必要な専門性が高く，タイムリーな 安全性情報の収集・提供, 並びに安全確保のための 迅速な意思決定が必要になることが紹介された。

実際に 18 万件を超える安全性情報（2015 年 1-12 月）を収集し，医学的見地から評価を行い，収集し た情報をグローバルデータベースに登録すること で，これを基に副作用のシグナル検出を実施し， 日・米・欧・アジアの各当局にスピーディに発信・ 開示している．近年開発されている多くの抗がん剂 やバイオ医薬品などの革新的新薬では, 全例調査の 実施に加え, 医療者への適切な情報提供や, 卸売企 業や調剂薬局も含めた流通管理の徹底や使用状況の 確認など，広範囲かつ厳格な管理が不可欠である. 個別化医療の進展や新たな作用メカニズムの医薬品 が開発される中で, 医療者がその医薬品の特性を理 解し, 適正に医薬品を使用するためには, 特に薬の 専門家たる薬剤師と安全性情報を豊富に有している 製薬会社が，「All Pharmacists for Patients」の下連 携し「育薬」を進めていくことが重要であることが 提案された.

明治薬科大学 植沢芳広博士より「大規模副作用 データベースと計算毒性学に基づく副作用予測」と いうタイトルで, 医薬品の副作用と関連する化学構 造上の特徵の把握は, 市販後調査の情報が限定され る新薬の副作用に対する注意喚起，不明な部分の多 い代謝物や危険ドラッグ等の毒性評価等に有用であ
るばかりでなく，創薬段階におけるシード化合物の フィルター，ドラッグリポジショニング，そして新 規薬効機序の解明の契機にもなり得ることが解説さ れた。ささらに，医薬品医療機器総合機構（Pharmaceuticals and Medical Devices Agency; PMDA) 及び米国食品医薬品局 (Food and Drug Administration； FDA）が公開している大規模副作用自発 報告データベース [各々 Japanese Adverse Drug Event Report (JADER) 及び FDA Adverse Event Reporting System (FAERS)] の内容を繙くための 計算毒性学的手法について, 具体例を用いて解説 し, 医薬品とその副作用の網羅的解析結果を視覚化 するための新規表示法である Volcano plotting が紹 介された。医薬品副作用の多くは機序不明の慢性毒 性であり予測が困難であるが，このような有害性発 現メカニズムを理解するためには，有害性発現経路 (adverse outcome pathway；AOP) の概念などを用 いることが今後重要になることも示された.

誰もが有害作用がない安全な薬物療法を望んでお り, 医薬品の使用には, 医薬品の有効性や有害作用 を十分に理解したうえで適正使用することが重要に なる，有害作用が発生した場合，速やかに原因薬剤 を特定し，迅速に対応することにより重症化を防ぐ こと，また，有害事象報告の収集解析からも，より 有効で安全な薬物治療の提案につながる。重篤な有 害事象の予防や回避，早期発見や発生予測，そして 有害事象が起きた際には被疑薬を早期に特定し対応 することは, 安全な薬物治療を行う上で重要であ り, 今後も薬学が果たす役割は重要になると考えら れる。 